\title{
Application of logistics model in analysing relationship marketing in travel agencies*
}

\author{
Katarina Borisavljević1, Gordana Radosavljevic ${ }^{2}$
}

\begin{abstract}
A concept of relationship marketing in tourism implies creating quality relations among all participants in the tourist supply chain. Analyzing the assumptions of the development of relations and their impact on the overall performance of companies in tourism is especially important. In this regard, the subject matter of this research is the application of relationship marketing in travel agencies in Serbia and the identification of key factors of loyalty of users of tourist services. This paper aims to investigate the influence of relationship marketing assumptions (such as trust, customer complaint management, investment in internal marketing, implementation of information technology in agencies, business image and tradition of agencies, as well as socio-demographic characteristics of clients) on the choice of travel agency through which clients will travel. The contribution of the paper is in the application of the logistics model in the research of relationship marketing in agencies. The results of this research have confirmed that investing in relational determinants in tourism leads both to the development of a long-term relationship with customers and to business performance improvement. Also, the results showed that customer profiles are important in the implementation of relationship marketing to increase the number of loyal customers in tourism. The importance of the paper is in proposing an efficient model for the application of relationship marketing in order to increase the level of customer loyalty in travel agencies operating on the Serbian market.
\end{abstract}

Key words: relationship marketing, travel agencies, logistics model, customer loyalty

JEL classification: Z33, M31

* Received: 26-08-2020; accepted: 24-05-2021

1 Assistant professor at University of Kragujevac, Faculty of Economics, Liceja Knezevine Srbije 3, 34000 Kragujevac, Serbia. Department of Management and Business Economics. Scientific affiliation: marketing and management in tourism and retaling. Phone: +38134303552 . E-mail: katarinab@kg.ac.rs. http://www.ekfak.kg.ac.rs/sr/nastavnici/nastavnici-pregled?id= $156 \& i d d=375$.

${ }^{2}$ Full professor at University of Kragujevac, Faculty of Economics, Liceja Knezevine Srbije 3, 34000 Kragujevac, Serbia. Department of Management and Business Economics. Scientific affiliation: marketing and management in tourism and retaling. Phone: +38134303568 . E-mail: gocar@kg.ac.rs.http://www.ekfak.kg.ac.rs/sr/nastavnici/nastavnici-pregled?id=156\&idd=158. 


\section{Introduction}

Applying the concept of relationship marketing is one of the key marketing paradigms leading to the shift from a transactional to a relational marketing approach, especially in the sector of providing services (Jones et al., 2018). Relationship marketing involves creating, maintaining, and improving relationships with customers and other stakeholders to achieve a mutual interest (Handriana, 2016). Unlike the traditional approach based on the application of marketing mix and mass marketing strategies aiming at attracting as many customers as possible in the first place, the relational approach is based on retaining existing customers and developing long-term and profitable relationships with them. Bearing in mind that the application of relationship marketing is significant in small and mediumsized businesses, it is crucial to analyze ways of applying these assumptions of relationship marketing in a sector of tourism.

The paper examines certain assumptions of the implementation of relationship marketing in travel agencies and how they affect customer loyalty. The study fills the existing research gap by applying a specific model for identifying the key determinants of relationship marketing in agencies. The significance of the model lies in the fact that it consists not only of well-known predictors of relationship marketing, like customer trust, internal marketing, management compliance, and quality of the website, but it also includes factors like business image and tradition, frequency of using services and socio-demographic characteristics examined in a limited number of studies. The main objective of this research is to investigate the influence of relationship marketing assumptions on the client's choice of a travel agency and the level of customer loyalty. The paper primarily contributes by introducing the application of the logistics model in the research of relationship marketing in tourism, which has not been applied in this field so far. In contrast to the classical linear regression model, the binary and ordinal logistics models examined customer attitudes such as whether they are loyal to a particular travel agency and identified relational assumptions that affect the increase in their degree of loyalty.

According to the subject and aim of the research, the paper is structured as follows. Besides Introduction and Concluding remarks, there are four sections. Section two gives an overview of existing literature about the assumptions and effects of relationship marketing in tourism. Section three represents the methodology used to estimate the impact of relationship marketing on customer loyalty in tourism. Sections four and five deal with empirical results and discussion of applying the ordinary and binary logistics models in travel agencies. 


\section{Theoretical background}

Based on the literature review, there is no universal and generally accepted definition of relationship marketing (Jones et al., 2018; Hunt et al., 2006; Gronroos, 1996; Gordon, 2008; Shammount, 2013; Gronroos, 1997; Gummesson, 1997; Berry, 1995; Hunt and Morgan, 1994). According to Gronroos (1996, p. 19), relationship marketing is the process of building, maintaining and improving relationships with customers and other stakeholders to realize common interests, and exchange products, services, values and ideas. Many authors (Ladhari, 2009; Palmatier et al., 2006; Doaei et al., 2011) have investigated the impact of improving the quality of tourism services on increasing customer satisfaction and loyalty, on positive WOM, on reducing employees turnover and minimizing costs, increasing market share and profitability of companies in the field of tourism.

According to these, many studies have pointed out key determinants of application of relationship marketing (such as trust, commitment, conflict management, communication, competence, empathy, customer attitudes, frequency of interaction, etc.) which all create a complex model of relationship marketing application (Chakiso, 2015; Handriana, 2016). Previous studies (e.g. Hea et al., 2018; Ndubisi and Nataraajan, 2018) have shown that the quality of relationships consists of a great number of dimensions and plays an important role in the customer decisionmaking process before, during, and after purchase. Many studies analyzed the trust and commitment (e.g. Hunt and Morgan, 1994; Brown et al., 2020; Payne and Flow, 2013; Young, 2006; Jones et al., 2010; Garbarino and Johnson, 1999; Aborumman et al., 2011) and customer compliance (e.g. Tronvoll, 2012; Kasabov and Warlow, 2010; Alvarez et al., 2011; Hua et al., 2019; Namkung et al., 2011). Previous research about customer complaint management process in tourism agencies showed that socio-demographic characteristics significantly influence their intention to complain to the agency (Borisavljevic and Radosavljevic, 2019). Also, results showed that customers would not complain if they had built trust and when the agency had built an image on the Serbian market.

Some of the dimensions of the relationship quality in tourism are tourists' satisfaction ( Crotts et al., 2009; Song et al., 2011; Hasegawa, 2010; Dominici and Guzzo, 2010; Hu et al., 2019) and their sense of devotion to a particular destination image ( Jalilvand et al., 2012; Akgüna et al., 2020; Almeida-Santana and Moreno-Gilbl. 2017; Pesonena et al., 2019) or company in tourism. The development of certain dimensions of the quality of relationships, such as internal relationships and the development of employees' knowledge in tourism companies, can significantly affect the level of customer satisfaction and loyalty ( Lombard and Steyn, 2008; Tortosa-Edo et al., 2010; Dogrua et al., 2019; Cătălin et al., 2014; Hill and Tombs, 2011; Herington et al., 2006; Cheng and Cho, 2011). For example, in the hotel business, the importance of the very moment when a guest meets the staff at the hotel reception is especially emphasized when evaluating the overall quality of the offer (Lenka et al., 2009). Also, 
customer trust is the basis for the development of quality relationships that affect their loyalty and purchase intentions (Handriana, 2016).

Based on literature of marketing tourism, there are many studies about customer satisfaction and loyalty in tourism (Zhang et al., 2014; Bo, 2018; Clemes et al., 2011; Akamavi et al., 2015; Pesonena et al., 2019; Rudež, 2010). In the aviation business, , in addition to the high level of quality of air transport services (flights are always on time or the concept right on time applied), building passengers' confidence regarding flight safety plays a significant role (Saha and Theingi, 2009). However, most of the research refers to the application of relationship marketing on the level of the tourist destination ( Almeida-Santanaa and Moreno-Gilbl., 2017; Pesonena et al., 2019; Dominici and Guzzo 2010; Shirazi and Som, 2013; Kim and Brown, 2012). The authors (Huang and Chiu, 2006) emphasized the special influence of the dimensions of relationship quality (trust, devotion, and tourist satisfaction) on the level of tourism destination loyalty. Also, Kim and Brown (2012) examined the role of perceived quality of the offer as visitor's experience, level of tourist expectations, and their socio-demographic and other characteristics on the degree of destination loyalty. The authors confirmed that their experience during the previous visit and the length of their stay had a decisive influence on tourists' decision to re-visit the same destination and to recommend it to others ( Gremler et al., 2011; Murphy et al., 2007).

In addition to informing and attracting new tourists, Web marketing activities and their implementation on the destination level significantly affect creating long-term relationships with tourists (Cobos et al., 2009; Buhalis and Law, 2008; Siegel, 2004; Álvarez et al., 2007). Also, destination image can significantly influence tourists' intention to choose a particular destination (Jalilvand et al., 2012), and hence, it influences the implementation of relationship marketing both on the level of tourist destinations and tourist companies.

The importance of the concept of online marketing has been emphasized in tourism lately (Ho and Lee, 2007; Chen and Kao, 2010; Kim et al., 2009; Nusair et al., 2011). Companies are increasingly focusing on creating and maintaining online relationships with their customers, so certain research has shown that $85 \%$ of customers maintain relationships with companies without direct contact (Steinhoff et al., 2019). However, there is little empirical evidence of the application of relationship marketing in tourism companies (such as hotels, agencies, airlines, etc.) that operate in the traditional way and by introducing online business. All this was an incentive for conducting some research regarding the application of relationship marketing in travel agencies in Serbia and for the identification of key factors of customer loyalty in the field of tourist services.

The development of e-business in the tourism sector has reduced or even eliminated the role of travel agencies as mediators. In order to survive and to increase market competitiveness, traditional agencies tend to improve the quality of their services and 
relationships with other participants in the tourism supply chain. The number of online agencies (such as Expedia, Travelocity, etc.) is increasing, as well as the number of providers offering online services, so that traditional agencies are increasingly shifting to a multi-channel approach of sales and to developing long-term relationships with their clients (Rajaobelina, 2018). Many authors (e.g. Hui and Wan, 2005; Rajaobelina, 2018; Lombard and Steyn, 2008; Ku and Fan, 2009; Moliner et al., 2007) believe that one of the key factors for the success of business agencies, apart from improving elements of marketing (quality of tourist offer, booking efficiency, promotion, business image, etc.) is developing quality relationships with service users.

Travel agencies have direct communication through personal contact in their branch offices or indirectly (via phone, email, website, social platforms, mobile applications and other forms of online communication). For these reasons, there is a development of the so-called hybrid relationships between agencies and users based on the application of a multi-channel approach to selling arrangements (Steinhoff et al., 2019). According to some authors (Sharma et al., 2020), the key dimensions of the quality of the agency's relationship with customers include satisfaction with their offer, trust and customer loyalty. Tourist satisfaction may be a consequence of the perceived value of the package arrangement, the previous experience of tourists and the level of their trust in the agency. The influence of the first impression that customers have while contacting the agency is particularly emphasized as their feelings and way of thinking have a strong impact on improving the quality of the relationship with the respective agency. Tourists' trust in the agency is based on honesty, good intentions, and being up to users' expectations. If the agency does not fulfill the given promises, tourists end all the contacts with the agency and do not return to the same agency (Moliner et al., 2007).

Travel agencies are increasingly facing different types of competition in the tourism market (Oppermann, 1999). Namely, tour operators tend to sell their arrangements directly to end-users. Avoiding the mediators, they reduce the profit margins of agencies. Also, airlines are reducing sales through agencies in order to increase profits and reduce additional commission costs. With the development of IT, hotels are also selling their accommodation packages via certain online booking platforms and are less and less using the services of mediators. Because of all this, agencies are increasingly shifting to implementing various relationship marketing strategies in order to increase the number of loyal customers. Developing and maintaining long-term relationships with clients implies implementing various concepts, such as creating databases and loyalty programs, CRM, online business, creating a well-known business image, efficient investment in internal marketing, customer complaints process, and similar. In this paper, we investigated the level of applied relationship marketing in agencies in Serbia that operate traditionally and those that operate via the Internet. We particularly emphasize the importance of relational factors and demographic characteristics of users regarding the choice of the travel 
agency and building customer loyalty towards the agency. According the aim and subject of the paper, the next one hypothesis and two sub hypotheses were tested:

$\mathrm{H}_{1}$ : The implementation of relationship marketing activities (customer trust, internal marketing, complaint management and web quality) in travel agencies influence the increase in the degree of loyalty of users of tourist services.

$\mathrm{H}_{1}$ a: The influence of relationship marketing activities on the degree of customer loyalty in agencies depends on their socio-demographic and behavioral characteristics.

$\mathrm{H}_{1 \mathrm{~b}}$ : The influence of relationship marketing on the degree of customer loyalty in agencies depends on the image of agencies and duration of that agency's business activities.

\section{Research methodology}

To achieve the goals of this research, we collected data on the attitudes of clients who use the services of travel agencies regarding the assessment of relationship marketing assumptions which have the greatest impact on increasing their loyalty i.e. on their tendency to return to the same agency or to recommend it to other potential users. Based on the previous research on the application of relationship marketing in the service sector, the questionnaire structure was adjusted (Kim et al., 2001; Ndubisi and Chan, 2005). The research was based on a sample of users of travel agencies' services from major cities in the Republic of Serbia. The sample can be considered a convenience sample which is common practice in marketing research (Soldić-Aleksić and Krasavac, 2009, p. 10). Field research was conducted in the period from October 2018 to January 2019. A total number of 469 respondents were interviewed and based on the total number of valid answers further processing and data analysis were performed.

Based on key assumptions of relationship marketing (such as the level of customer trust, the level of communication, and competence of employees, the process of managing customer complaints and the application of information technology in travel agencies) the research model included several main independent variables and one dependent variable. Each independent variable was measured by specific statements/questions. Respondents expressed their opinions on a five-point Likert scale $(1-$ strongly disagree, 5 - strongly agree). The statements were formulated based on the relevant literature review. Customer trust was measured through four statements, which were formulated based on the studies conducted by Ndbusi et al. (2007), Medina - Munos and Garcia - Falcon (2000) and Negi and Ketema (2010). Internal marketing was measured by using four statements taken from Ndbusi et al. (2007), Kim et al. (2001), Sin et al. (2002) and modified to meet the requirements of 
our research. Ndubisi (2007) and Ndbusi and Wah (2005) were used as the basis for formulating three statements by which Complaint management was measured. For measuring Quality of web site two statements were taken from Chen and Kao, (2010) and Kim et al. (2009), and adapted to meet the needs of our research. Finally, to measure dependent variable Customer loyalty, we took two statements from Ndbusi et al. (2007) and Kim et al. (2001) and adapted them in line with the objectives of our research. The variable Loyalty in the binary logistics model was measured by the willingness of customers to recommend the agency to others or to return to the same agency. Also, the level of customer loyalty (low, moderate and high level of loyalty) was based on question relating to how many times they use the services of one agency and this variable represented a dependent variable in the ordinary logistics model.

The structure of the research sample was given in Annex 1. The analysis of sociodemographic and behavioral characteristics of the respondents (gender, age, education, monthly income, frequency of travel during the year) was given through descriptive statistics. The results of descriptive statistics showed that women participate with $60 \%$ in the sample and that the largest percentage of respondents is with high school degree of education (44.9\%) but also there is large percentage of highly educated users $(37.2 \%)$. It is interesting that the largest percentage of respondents generally travel once a year (53.1\%) and most respondents are between 18 and 40 years old. In terms of the monthly household income, the highest percentage of respondents has income between 100 and 500 euro's (37\%) but also many of them has income more than 1000 euro's $(33.2 \%)$. In the paper, we proposed a conceptual model of application of relationship marketing in travel agencies (Figure 1), based on the analysis of the attitudes of service users on the business of travel agencies in Serbia which perform their activities in the traditional way and via the Internet.

Figure 1: Conceptual model of relationship marketing in travel agencies

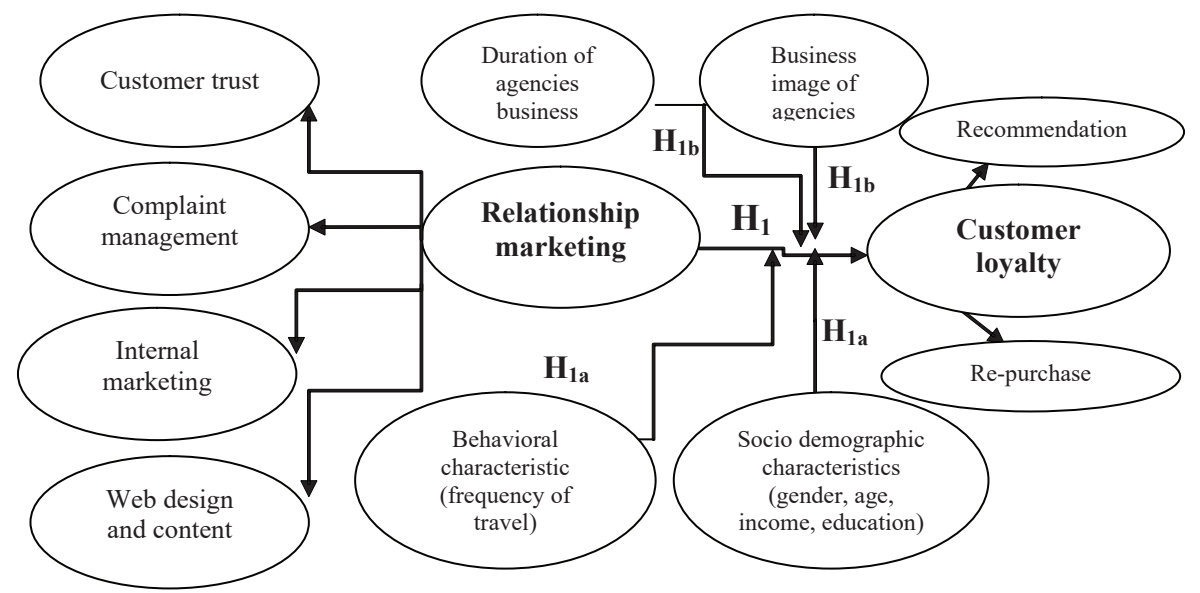

Source: Authors calculation 


\section{Empirical data and analysis}

The methodology of researching users' attitudes towards the assumptions of the application of relationship marketing in travel agencies in Serbia is based on the application of the logistics models which were done in the Statistical Package for Social Sciences (SPSS 22.0) and AMOS 24.0 software. In the binary logistics model, the dependent variable has values of 0 or 1 , and within the logistics model of ordered logistic regression, the dependent variable has more than two modalities (Nojković, 2007). The aim of the analysis is to determine the level of customer loyalty, as well as to identify the factors which have influence on the increase of their loyalty. The research was conducted based on the binary and ordinal logistic regression, since customer loyalty can have two modalities (loyal and disloyal customer) or more modalities (high, moderate and low customer loyalty). With factor analysis, a large number of variables (questions) were connected and grouped within the key factors of relationship marketing. The Principal Component Analysis (PCA) method was used to simplify the data and reduce the number of variables. As the rotation method, it was used the Varimax raw rotation (Table 1).

Table 1: The matrix of factor loadings

\begin{tabular}{|l|l|l|l|l|}
\hline \multicolumn{1}{|c|}{ Items } & & & \\
& & & & \\
\hline $\begin{array}{l}\text { Consistency of your travel agency when it comes to providing quality } \\
\text { service }\end{array}$ & 0.882 & & & \\
\hline The level of trust in your travel agency & 0.805 & & & \\
\hline The employees of your travel agency respect their clients & 0.796 & 0.310 & & \\
\hline Your travel agency keep its promises when providing its services & 0.662 & & 0.432 & \\
\hline $\begin{array}{l}\text { The satisfaction in communication with the employees of your travel } \\
\text { agency }\end{array}$ & & 0.840 & & \\
\hline $\begin{array}{l}\text { The level of knowledge of the employees in your travel agency about } \\
\text { the tourist offer }\end{array}$ & & 0.821 & & \\
\hline The employees of your travel agency provide you with advisory services & & 0.632 & 0.408 & \\
\hline $\begin{array}{l}\text { The employees of your travel agency provide you with reliable } \\
\text { information }\end{array}$ & & 0.469 & 0.403 & 0.345 \\
\hline $\begin{array}{l}\text { The willingness of your travel agency to listen to your problems and } \\
\text { find the best solution for you }\end{array}$ & & & 0.842 & \\
\hline $\begin{array}{l}\text { The efficiency of the employees in your travel agency when it comes } \\
\text { to solving customers' complaints }\end{array}$ & & & 0.802 & \\
\hline Your travel agency try to avoid potential problems & 0.410 & 0.308 & 0.592 & \\
\hline The receiving the necessary information through your agency's website & & & & 0.830 \\
\hline $\begin{array}{l}\text { The satisfaction with the appearance and design of your travel } \\
\text { agency's website }\end{array}$ & & 0.309 & & 0.825 \\
\hline
\end{tabular}

Source: Authors calculation 
In order to check whether the set of data is suitable for factor analysis and to analize the correlation between variables, we carried out the so-called KMO (KaiserMayer-Olkin) and Bartlett's Test . If the value of KMO is between 0.5 and 1, and the the Bartlett test value is statistically significant, it would confirm the justification of the factor analysis, and that these items are essential for the study (Soldic-Aleksic and Krasavac, 2009, p. 206). In this case, the value of KMO was 0.799 and the Bartlett test value was significant in the factor analysis $(\mathrm{p}=0.00)$.

Based on the factor analysis (Table 1) one can conclude that the following factors were used in further research: customer trust, design and content of the agencies' websites, the process of managing customers' complaints, and the level of applying internal marketing in travel agencies. The reliability of the survey questionnaire was checked. The most common measurement system is through the reliability of the internal consistency, i.e. the calculation of the Cronbach's alpha coefficient that is 0.87 for whole scale with acceptable values of the coefficient above 0.7 (customer trust $=0.82$; customer compliance $=0.73$; internal marketing $=0.73$; web content and design $=0.67$ ).

Convergent validity and discriminant validity were also tested. The model is characterized by convergent validity since the average variance extracted (AVE) of each construct was higher than 0.5 Composite reliability (CR) values of each variable were higher than AVE values, which further confirmed convergent validity. According to the Fornell-Larcker criterion (Fornell and Larcker, 1981) and due to the fact the square root of each construct's AVE is higher than the latent variables correlation, the discriminant validity has been achieved (Annex 2). Also, the HTMT criteria, which are based on a comparison of the heterotrait-heteromethod correlations and the monotrait-heteromethod correlations, identify a lack of discriminant validity (Henseler et al., 2015). If the value of the HTMT is higher than predefined threshold, it can be concluded that there is a lack of discriminant validity. We computed the HTMT criteria for each pair of constructs on the basis of the item correlations (Annex 2). Comparing these results with the threshold values as defined in $\mathrm{HTMT}_{0.85}$ we concluded that all of them were lower than 0.85 and that discriminant validity has been achieved.

\subsection{The application of the ordinal logistics model}

The application of the ordinal logistics model was used in order to examine the impact of relational assumptions (such as: customer trust, design and content of the agencies' websites, the process of managing customers' complaints and the level of applying internal marketing in travel agencies) as well as socio demographic and other characteristics of the clients, on the degree of their loyalty towards the travel agency. By using the ordinal logistic regression, we examined the impact of assumptions regarding relationship marketing, image, and the duration of the agency's business activities on the degree of their customer loyalty, that is, the variable which takes more than two values. The degree of customer loyalty was analyzed based on a 
question that reads "How many times customers used the services of the same travel agency?" which is measured by an ordinary scale. The dependent variable in this ordinal model has multiple modalities (high, moderate, and low customer loyalty). Most of customers used the service from the same agency once $(38.2 \%)$ or two and three times (34.6\%) (table 2). One modality of the dependent variable ('once') was taken as the reference category in the model. The independent variables were transformed into categorical variables (e.g. two categories of customer trust are: low (1) and high level of trust (2)). Respondents with a lower level of trust belonged to the group of those who expressed the lowest degrees of agreement on the Likert scale (e.g. they chose completely (1) disagree and disagree (2)) regarding the level of trust in the agency, and vice versa. As is always the case with categorical predictors in models with intercepts, the number of coefficients displayed is one less than the number of categories of the variable. Based on that, a comprehensive model of applying relationship marketing in tourism was proposed. After several iterations, the final model was presented (Table 2) with statistically significant variables whose significance of the test is less than the limit value of $10 \%(\mathrm{p}<0.10)$.

Based on the results of the parallel test or by doing the Brant test, it can be concluded that the assumption about the parallelism was not met and that there are differences in the relationships between the independent variables and the dependent variable (the outcome) in all three possible outcomes (the degree of customer loyalty). The null hypothesis is rejected. It indicates that the impact of the variables on the thresholds (possible outcomes) is different or that there are differences in the significance of the variables for the possible outcomes in the logistics model. However, by using the so-called Gologit2 (General Ordinar Logit) or Partial General Ordinar Logit, additional analysis can be performed in order to overcome the given limitation of the logistics model and to accept the null hypothesis (when the statistical significance of the $\mathrm{X}^{2}$ test is higher than the limit value $\mathrm{p}=0.05$ ), which indicates that there are no differences in the significance of the observed variables between the outcomes 0 and 1 , and there are no differences between the outcomes 1 and 2 in the model either. In the final model, the thresholds are statistically significant, which indicates that the assumption that there is a clear difference among the three loyalty categories, that is, between two possible outcomes, ( 0 and 1 or 1 and 2$)$ is met (as shown in Table 2).

Table 2: The impact of applying relationship marketing, socio demographic characteristics of the clients, agency's image and the duration of its business activities on the degree of the customer loyalty

\begin{tabular}{|c|c|c|c|}
\hline \multicolumn{5}{|c|}{ Model Fitting Information } \\
\hline Model & -2 Log Likelihood & Chi-Square & Sig. \\
\hline Intercept Only & 231.578 & & \\
\hline Final & 167.019 & 64.559 & 0.000 \\
\hline
\end{tabular}


Katarina Borisavljević, Gordana Radosavljević • Application of logistics model in analysing...

\begin{tabular}{|c|c|c|}
\hline \multicolumn{3}{|c|}{ Goodness-of-Fit } \\
\hline & Chi-Square & Sig. \\
\hline Pearson & 133.735 & 0.000 \\
\hline Deviance & 118.608 & 0.000 \\
\hline
\end{tabular}

\begin{tabular}{|c|c|}
\hline \multicolumn{2}{|c|}{ Pseudo R-Square } \\
\hline Cox and Snell & 0.155 \\
\hline Nagelkerke & 0.175 \\
\hline McFadden & 0.078 \\
\hline
\end{tabular}

\begin{tabular}{|l|c|c|c|}
\hline \multicolumn{3}{|c|}{ Case Processing Summary } \\
\hline \multirow{2}{*}{} & & $N$ & $\begin{array}{c}\text { Marginal } \\
\text { Percentage }\end{array}$ \\
\hline \multirow{2}{*}{$\begin{array}{l}\text { How many times you used the services } \\
\text { of the same travel agency? }\end{array}$} & once & 146 & $38.2 \%$ \\
\cline { 2 - 4 } & two or three times & 132 & $34.6 \%$ \\
\hline \multirow{2}{*}{ Trust } & four times and more & 104 & $27.2 \%$ \\
\hline \multirow{2}{*}{ Complaint management } & 1.00 & 55 & $14.4 \%$ \\
\hline \multirow{2}{*}{ Internal marketing } & 2.00 & 327 & $85.6 \%$ \\
\hline \multirow{2}{*}{ Web design } & 1.00 & 67 & $17.5 \%$ \\
\hline \multirow{2}{*}{ Education } & 2.00 & 315 & $82.5 \%$ \\
\hline Valid & 1.00 & 58 & $15.2 \%$ \\
\hline Missing & 2.00 & 324 & $84.8 \%$ \\
\hline Total & 1.00 & 101 & $26.4 \%$ \\
\cline { 2 - 4 } & 2.00 & 281 & $73.6 \%$ \\
\cline { 2 - 4 } & 1.00 & 173 & $45.3 \%$ \\
\hline
\end{tabular}

\begin{tabular}{|c|c|c|c|c|c|c|c|}
\hline \multicolumn{8}{|c|}{ Parameter Estimates } \\
\hline & & \multirow{2}{*}{ Estimate } & \multirow{2}{*}{$\begin{array}{l}\text { Stand. } \\
\text { Error }\end{array}$} & \multirow{2}{*}{ Wald } & \multirow{2}{*}{ Sig. } & \multicolumn{2}{|c|}{$\begin{array}{l}\text { 95\% Confidence } \\
\text { Interval }\end{array}$} \\
\hline & & & & & & $\begin{array}{l}\text { Lower } \\
\text { Bound }\end{array}$ & $\begin{array}{l}\text { Upper } \\
\text { Bound }\end{array}$ \\
\hline \multirow{2}{*}{ Threshold } & [ordinal $=1.00]$ & -1.244 & 0.169 & 54.408 & 0.000 & -1.575 & -0.914 \\
\hline & [ordinal $=2.00]$ & 0.418 & 0.156 & 7.170 & 0.007 & 0.112 & 0.725 \\
\hline \multirow{10}{*}{ Location } & {$[$ trust $=1.00]$} & -1.111 & 0.328 & 11.465 & 0.001 & -1.754 & -0.468 \\
\hline & {$[$ trust $=2.00]$} & 0 & . & & . & . & . \\
\hline & [complaint management $=1.00]$ & 0.268 & 0.440 & 0.370 & 0.543 & -0.595 & 1.130 \\
\hline & [complaint management $=2.00$ ] & 0 & . &. & . & . &. \\
\hline & [internal marketing $=1.00]$ & -0.797 & 0.341 & 5.476 & 0.019 & -1.465 & -0.130 \\
\hline & [internal marketing $=2.00]$ & 0 & . & . & . & . & . \\
\hline & {$[$ web design $=1.00]$} & -1.276 & 0.400 & 10.183 & 0.001 & -2.059 & -0.492 \\
\hline & [web design =2.00] & 0 & . & . &. & . & . \\
\hline & [education $=1.00]$ & -0.334 & 0.198 & 2.837 & 0.092 & -0.722 & 0.055 \\
\hline & [education $=2.00]$ & 0 & . & . & . &. & . \\
\hline
\end{tabular}

Source: Authors calculation 
According to the results of the ordinal logistic regression, it can be concluded that statistically significant relational assumptions are those that are related to the level of investment in internal marketing, design and content of the agencies'websites and the level of customer trust. In addition, besides the significant assumptions regarding the application of relationship marketing, the level of the customers' education also significantly affects the degree of their loyalty to a certain travel agency. Based on the final model, which only includes statistically significant variables, certain conclusions can be drawn. It is less likely that the clients who have a lower level of trust in a certain agency (which they used the last time) will use the same agency more often than those clients who have a higher level of trust in the agency. Then, it is less likely that the clients who are not satisfied with the employees' knowledge and the way they treated them will return to the same agency, compared to those clients who are satisfied with the communication and the cooperation with the agency's employees. In addition, it is less likely that the clients who are not satisfied with the internet offer of the agency will use the services of the same agency more than once, compared to those clients who are satisfied with the content and design of the website of the agency they used the last time. Finally, it is less likely that clients with a lower level of education will travel using the same agency three or more times, compared to clients with a higher level of education.

\subsection{The application of the binary logistics model}

Customer loyalty, which represents a dependent variable in the model, can have values 0 or 1 , when analyzing clients' decisions that they will use the services of the agency again regardless of the higher price of the offer compared to the competition or their decisions about whether they will recommend the services to other potential clients. Most of them (about 72\%) would like to go back and use the services of the agency again and recommend the agency to others. The customer loyalty can have two modalities (loyal and disloyal customer). By applying the binary logistic regression, the impact of individual assumptions on customer loyalty can be examined. By using the following model, the impact of assumptions regarding the application of relationship marketing and the clients' socio-demographic characteristics on the level of their loyalty to the agency can be examined (Table 3). Starting from the initial model, the paper analyzes the impact of all assumptions of relationship marketing, business image and tradition of agencies, as well as the impact of certain sociodemographic and behavioral characteristics of users. By conducting regression analyses, final models were obtained that include only statistically significant variables. 
Katarina Borisavljević, Gordana Radosavljević • Application of logistics model in analysing...

Table 3: The impact of applying relationship marketing and the clients' sociodemographic characteristics on the possibility of giving recommendations to other clients

\begin{tabular}{|c|c|c|c|}
\hline \multicolumn{3}{|c|}{ Model Summary } \\
\hline Step & -2 Log likelihood & $\begin{array}{c}\text { Cox \& Snell R } \\
\text { Square }\end{array}$ & $\begin{array}{c}\text { Nagelkerke R } \\
\text { Square }\end{array}$ \\
\hline 1 & 111.093 & 0.251 & 0.486 \\
\hline
\end{tabular}

\begin{tabular}{|c|c|c|c|c|c|}
\hline \multicolumn{6}{|c|}{ Classification Table } \\
\hline & \multirow{3}{*}{\multicolumn{2}{|c|}{ Observed }} & \multicolumn{3}{|c|}{ Predicted } \\
\hline & & & \multicolumn{2}{|c|}{$\begin{array}{l}\text { Would you gladly recommend } \\
\text { your travel agency to others? }\end{array}$} & \multirow{2}{*}{$\begin{array}{l}\text { Percentage } \\
\text { Correct }\end{array}$} \\
\hline & & & no & yes & \\
\hline \multirow{3}{*}{ Step 1} & \multirow{2}{*}{$\begin{array}{l}\text { Would you gladly recommend } \\
\text { your travel agency to others? }\end{array}$} & no & 15 & 15 & 50.0 \\
\hline & & yes & 4 & 220 & 98.2 \\
\hline & \multicolumn{2}{|l|}{ Overall Percentage } & & & 92.5 \\
\hline
\end{tabular}

\begin{tabular}{|l|c|c|c|c|c|}
\hline \multicolumn{7}{|c|}{ Variables in the Equation } \\
\hline & B & S.E. & Wald & Sig. & Exp(B) \\
\hline Web design & 0.928 & 0.302 & 9.415 & 0.002 & 2.530 \\
\hline Web content & 0.465 & 0.247 & 3.546 & 0.060 & 1.592 \\
\hline Travel frequency & 1.883 & 0.603 & 9.738 & 0.002 & 6.572 \\
\hline Income & 0.000 & 0.000 & 11.090 & 0.001 & 1.000 \\
\hline Trust & 2.658 & 0.633 & 17.623 & 0.000 & 14.263 \\
\hline Complaint management & 1.858 & 0.571 & 10.578 & 0.001 & 6.412 \\
\hline Age of respondents & 0.035 & 0.020 & 3.025 & 0.082 & 1.036 \\
\hline Constant & -13.401 & 2.623 & 26.100 & 0.000 & 0.000 \\
\hline
\end{tabular}

Source: Authors calculation

Based on the final binary model (shown in Table 3 ), the results have proved the significance of the following factors - complaint management in the agency, content and design of the agency's website, income per household member, travel frequency, clients' age, as well as the level of trust in the agency - for the increase in the number of recommendations and the communication of the client's positive experience with other potential clients. Namely, the results have shown that travel frequency affects customer loyalty. By determining the quotient of the relationship between the likelihood of two outcomes, certain conclusions can be drawn. The likelihood that the clients will recommend the agency's services to others increases by $557.2 \%(\mathrm{OR}=6.572 ; \mathrm{p}=0.005)$ when the clients' travel frequency increases in a single unit, that is for those who travel two or more times in a year, compared to people who use the agency's services once a year. It is also interesting that the 
likelihood that the clients will recommend the agency's services to others increases only by $3.6 \%$ with the increase in the clients' age, under the condition that the other factors are the same in the model $(\mathrm{OR}=1.036,9, \mathrm{p}=0.010)$. The following model (in Table 4) examines the impact of relational factors and the clients' characteristics on the degree of their loyalty to the agency (which refers to their decision to use the services of the same agency again). The results of the binary logistic regression have shown that statistically significant variables (complaint management, the duration of the agency's business activities, clients' age, investment in internal marketing, income per household member, website design, the level of customer trust and the household's average spending on travel) affect the clients' decision to go back and use the services of the same agency again. The final model presents significant variables (Table 4).

Table 4: The impact of assumptions related to the application of relationship marketing in an agency on the clients' decision to use the services of the same agency again

\begin{tabular}{|c|c|c|c|}
\hline \multicolumn{3}{|c|}{ Model Summary } \\
\hline Step & -2 Log likelihood & $\begin{array}{c}\text { Cox \& Snell R } \\
\text { Square }\end{array}$ & $\begin{array}{c}\text { Nagelkerke R } \\
\text { Square }\end{array}$ \\
\hline 1 & 170.854 & 0.197 & 0.373 \\
\hline
\end{tabular}

\begin{tabular}{|l|l|c|c|c|}
\hline \multicolumn{5}{|c|}{ Classification Table } \\
\hline \multirow{2}{*}{\begin{tabular}{l} 
Observed \\
\cline { 3 - 4 }
\end{tabular}} & \multicolumn{3}{c|}{$\begin{array}{c}\text { Would you use the services of } \\
\text { your travel agency again? }\end{array}$} & $\begin{array}{c}\text { Percentage } \\
\text { Correct }\end{array}$ \\
\cline { 3 - 4 } & & no & yes & \\
\cline { 3 - 5 } $\begin{array}{l}\text { Would you go back and use the } \\
\text { services of your travel agency again? }\end{array}$ & yes & 14 & 26 & 35.0 \\
\hline Overall Percentage & & 276 & 98.2 \\
\hline
\end{tabular}

Variables in the Equation

\begin{tabular}{lccccc}
\hline & B & S.E. & Wald & Sig. & Exp(B) \\
\hline Complaint management & 2.288 & 0.447 & 26.213 & 0.000 & 9.855 \\
\hline Age of respondents & -0.008 & 0.015 & 0.287 & 0.592 & 0.992 \\
\hline Education & -0.700 & 0.421 & 2.761 & 0.097 & 0.496 \\
\hline Web design & 1.281 & 0.217 & 34.768 & 0.000 & 3.601 \\
\hline Constant & -4.922 & 1.402 & 12.323 & 0.000 & 0.007
\end{tabular}

Source: Authors calculation 
Based on this final model, it can be concluded that the process of managing the clients' complaints, website design, as well as the clients' level of education and age are statistically significant variables when it comes to the increase in the degree of customer loyalty and their decision to return to the same agency.

By determining the quotient of the relationship between the likelihood of two outcomes, certain conclusions can be drawn. The likelihood that clients will return to the same agency is higher by $885 \%(\mathrm{OR}=9.885 ; \mathrm{p}=0.0005)$ if the efficiency of the complaint management process increases in a single unit. With an increase in the clients' satisfaction level, the chance that they will visit the agency's website again and use its services increases by $260 \%(\mathrm{OR}=3.601, \mathrm{p}=0.0005)$.

\section{Results and discussion}

Based on the calculated indicators about the validity of the examined models, the most important factors that affect customer loyalty to the travel agency services in Serbia have been identified. The significance of the research is in analyzing the impact of relationship marketing assumptions on varying degrees of customer loyalty in tourism sector. The previous studies (Chakiso, 2015; Ndubisi, 2007; Negi and Ketema, 2010; Sin et al., 2002) were based on influencing the main relationship marketing activities (customer trust, internal marketing, management compliance and web quality) on customer loyalty in the service sector, but they did not explore the application of this concept in tourism. In addition, the paper examined the importance of additional relational variables, as well as the business image and length of business of tourist agencies to the degree of customer loyalty which was different from other relationship marketing research.

In relation to previous analyses (Jones et al., 2018; Álvarez et al., 2007), the proposed model in the paper explains the process of carrying out relationship marketing and points out the connection among relational assumptions, customers' socio-demographic and behavioral characteristics and the specificity of travel agencies' business activities, whose purpose is to increase the degree of loyalty in end customers. The model starts from meeting certain prerequisites related to the application of relationship marketing, which refers to building trust in customers, efficiently managing their complaints in agencies, the level of investment in internal marketing and the creation of the agencies' website suitable design and content. In addition, the impact of website design and content on the loyalty of customers who buy services in a traditional way or using the internet is also significant. Besides the efficient complaint management process, the way the agency's employees treat clients, together with the duration of the agency's business activities, considerably affects clients when it comes to deciding to use the services of the same agency again. Depending on the clients' age and the amount of their monthly income, they 
will recommend the agency's services to others, whereas their level of education will significantly affect their decision to travel using the same agency's services again.

Based on these, it can be concluded that the main hypothesis and first subhypothesis were partially confirmed, because some relational factors were statistically significant in increasing customer loyalty which was measured by their willingness to recommend or return to the same agency. The relational variables (such as: trust, internal marketing, web design and level of customer education) were significant in measuring the level of loyalty. Also, the results showed that the business image and duration of agency's business were not significant factors in the application of relationship marketing in order to increase the degree of customer loyalty, so the second sub-hypothesis was rejected.

The scientific contribution of the paper is reflected in expanding the knowledge on relational models and on assumptions regarding the application of relationship marketing in tourism, which have not been the subject of previous research conducted in this field. Namely, there are not papers that focused only on the implementation of the relational concept in various tourism activities, but papers were more based on the assumptions of the application of the CRM concept, of direct or digital or viral marketing. This indicates the necessity of studying the concept of relationship marketing in modern marketing theory as well as its connection to other concepts that can also be applied in the field of tourism. The practical contribution of the research refers to proposing the application of a comprehensive relational model in tourist companies operating on the Serbian market. The results of our research confirmed that continuous investment in key relational determinants in business leads to the development and maintenance of long-term relationships with customers, thus increasing the level of their loyalty. In particular, customer profiles (in terms of their socio-demographic and behavioral characteristics) are taken into account when performing relationship marketing activities in order to identify target groups of customers who contribute to improving the business performance of companies in the field of tourism.

\section{Conclusions}

The research results strongly pinpoint the travel agencies' need to address those determinants that have proven to be statistically significant for the increase in the degree of customer loyalty in the research. A special focus should be on factors contributing to increasing customer loyalty the most and other factors such as business image and duration of business activities. All of them contribute to a stronger impact of the main assumptions regarding the application of relationship marketing on customer loyalty because there are differences in the clients' 
opinions regarding which assumptions need to be met. One of the paper's limitations refers to the analysis of travel agencies that do business in a traditional way as well as using the Internet, but not of agencies that offer only online tourist services.

Considering the increasing application of strategies related to online relationship marketing, online travel agencies can be the subject of special analysis. Also, the limitation of the paper refers to the application of relationship marketing only in travel agencies. The subject of additional analysis may be the application of marketing relations at the level of tourist destinations or in other areas of tourism (hospitality, restaurant business, air transport, etc.). Future research can also look at the impact of special exogenous factors on the act of conducting relationship marketing activities in agencies (for example, the impact of the pandemic on the agencies' business activities). It is important to examine the impact of relationship marketing on the overall business performance of companies in tourism, primarily on financial performance and the application of social responsibility in tourism. In addition to determining the degree of customer loyalty, the rate of their retention or departure from the company can be determined, as well as the reasons that influenced their decision to leave the company.

Since the highest source of income in tourism is achieved precisely by developing quality relationships, the significance of this paper lies in giving recommendations for a more efficient application of the relationship marketing concept and an increase in the level of customer loyalty in travel agencies. The practical goal is to consider the current level of relationship marketing in travel agencies in Serbia, developing awareness of the need for broader application of this concept and giving recommendations to managers and employees in improving the marketing performance of tourism companies.

\section{References}

Aborumman, A., Alhawary, F., Irtaimeh, H. (2011) "Enhancing holiday travelers loyalty toward traveling agents through the relationship quality: an empirical study on the Jordanian travelers", International Journal of Academic Research, Vol. 3, No. 4, pp. 461-467.

Akamavi, R. et al. (2015) "Key determinants of passenger loyalty in the low-cost airline business", Tourism Management, Vol. 46, No. C, pp. 528-545, doi: 10.1016/j.tourman.2014.07.010.

Akgüna, A. et al. (2020) "The relationships among nostalgic emotion, destination images and tourist behaviors: An empirical study of Istanbul", Journal of Destination Marketing \& Management, Vol. 16, pp. 1-13, doi: 10.1016/j. jdmm.2019.03.009. 
Almeida-Santanaa, A., Moreno-Gilbl, S. (2017) "New trends in information search and their influence on destination loyalty: Digital destinations and relationship marketing", Journal of Destination Marketing \& Management, Vol. 6, No. 2, pp. 150-161, doi: 10.1016/j.jdmm.2017.02.003.

Alvarez, L., Casielles, R., Mart, A. (2011) "Analysis of the role of complaint management in the context of relationship marketing", Journal of Marketing Management, Vol. 27, No. 1-2, pp. 143-164, https://doi.org/10.1080/ 02672571003719088.

Álvarez, L., Martín, A., Casielles, R. (2007) "Relationship marketing and information and communication technologies: analysis of retail travel agencies", Journal of Travel Research, Vol. 45, No. 4, pp. 453-463, https://doi. org/10.1177/0047287507299593.

Berry, L. (1995) "Relationship marketing of services, growing interest, emerging perspectives", Journal of the Academy of Marketing Science, Vol. 23, No. 4, pp. 236-245, https://doi.org/10.1177/009207039502300402.

Bo, G. (2018) "Proposal and validation of a Theoretical Model of Costumer retention determinants in Service Environment", RAUSP Management Journal, Vol. 53, No. 2, pp. 202-213, https://doi.org/10.1016/j.rauspm.2017.06.004.

Borisavljević, K. Radosavljević, G. (2019) "Upravljanje žalbama kupaca u turističkim agencijama", Teme, Vol. 43, No. 2, pp. 543-555, https://doi. org/10.22190/TEME180512033B.

Brown, J., Crosno, J., Tong, P. (2020) "Is the theory of trust and commitment in marketing relationships incomplete?", Industrial Marketing Management, doi: 10.1016/j.indmarman.2018.10.005.

Buhalis, D., Law, R. (2008) "Progress in information technology and tourism management: 20 years on and 10 years after Internet-The state of e-Tourism research", Tourism Management, Vol. 29, No. 4, pp. 609-623, doi: 10.1016/j. tourman.2008.01.005.

Cătălin, M., Andreea P., Adina, C. (2014) “A holistic approach on internal marketing implementation", Business Management Dynamics, Vol. 3, No. 11, pp. 09-17, doi: 10.13140/2.1.1790.0163.

Chakiso, C. (2015) "The effect of relationship marketing on customers' loyalty (Evidence from Zemen Bank)", Emerging Markets Journal, Vol. 5, No. 2, pp. 58-70, doi: 10.5195/emaj.2015.84.

Chen, C., Kao, Y. (2010) "Relationships between process quality, outcome quality, satisfaction, and behavioral intentions for online travel agencies - evidence from Taiwan", The Service Industries Journal, Vol. 30, No. 12, pp. 2081-2092, doi: 10.1080/02642060903191108.

Cheng, S., Cho, V. (2011) “An integrated model of employees' behavioral intention toward innovative information and communication technologies in travel 
agencies", Journal of Hospitality \& Tourism Research, Vol. 35, No. 4, pp. 488510, https://doi.org/10.1177/1096348010384598.

Clemes, M., Gan, C., Ren, M. (2011) "Synthesizing the effects of service quality, value, and customer satisfaction on behavioral intentions in the motel industry: an empirical analysis", Journal of Hospitality \& Tourism Research, Vol. 35, No. 4, pp. 530-568, https://doi.org/10.1177/1096348010382239.

Cobos, L., Wang, Y., Okumus, F. (2009) "Assessing the Web-Based Destination Marketing Activities: A Relationship Marketing Perspective", Journal of Hospitality Marketing \& Management, Vol. 18, No. 4, pp. 421-444, doi: 10.1080/19368620902799643.

Crotts, J., Mason, P., Davis, B. (2009) "Measuring guest satisfaction and competitive position in the hospitality and tourism industry", Journal of Travel Research, Vol. 48, No. 2, pp. 139-151, https://doi.org/10.1177/0047287508328795.

Doaei, H., Rezaei, A., Khajei, R. (2011) "The impact of relationship marketing tactics on customer loyalty: the mediation role of relationship quality", International Journal of Business Administration, Vol. 2, No. 3, pp. 83-93, https://doi.org/10.5430/ijba.v2n3p83.

Dogrua, T. et al. (2019) "Employee earnings growth in the leisure and hospitality industry", Tourism Management, Vol. 74, pp. 1-11, https://doi.org/10.1016/j. tourman.2019.02.008.

Dominici, G., Guzzo, R. (2010) "Customer satisfaction in the hotel industry: a case study from Sicily", International Journal of Marketing Studies, Vol. 2, No. 2, pp. 3-12, doi: 10.5539/ijms.v2n2p3.

Fornell, C., Larcker, D. (1981) "Evaluating Structural Equation Models with Unobservable Variables and Measurement Error", Journal of Marketing Research, Vol. 18, pp. 39-50, doi: 10.2307/3151312.

Garbarino, E., Johnson, M. (1999) "The different roles of satisfaction, trust, and commitment in customer relationships", Journal of Marketing, Vol. 63, No. 2, pp. 70-87, doi: 10.2307/1251946.

Gordon, T. (2008) "The relationship marketing orientation of Hong Kong financial services industry managers and its links to business performance", Journal of Financial Services Marketing, Vol. 13, No.3, pp. 193-203, doi: 10.1057/ fsm.2008.22.

Gremler, D., Gwinner, K., Brown, S. (2001) "Generating positive word-of-mouth communication through customer-employee relationships", International Journal of Service Industry Management, Vol. 12, No. 19, pp. 44-59, doi: 10.1108/09564230110382763.

Gronroos, C. (1996) "Relationship marketing: strategic and tactical implications", Management Decision, Vol. 34, No. 3, pp. 5-14, doi: 10.1108/ 00251749610113613. 
Gronroos, C. (1997) "Keynote paper, From marketing mix to relationship marketing -towards a paradigm shift in marketing", Management Decision, Vol. 35, No. 4, pp. 322-339, doi: http://dx.doi.org/10.1108/00251749410054774.

Gummesson, E. (1997) "Relationship marketing as a paradigm shift: some conclusions from the 30R approach", Management Decision, Vol. 35, No. 4, pp. 267-272, doi: https://doi.org/10.1108/00251749710169648.

Handriana, T. (2016) "The Role of Relationship Marketing in Small and Medium Enterprises (SMEs)", Journal Pengurusan, Vol. 48, pp. 1-18, http://dx.doi. org/10.17576.

Hasegawa, H. (2010) “Analyzing tourists' satisfaction: A multivariate ordered probit approach", Tourism Management, Vol. 31, No. 1, pp. 86-97, doi: 10.1016/j.tourman.2009.01.008.

Hea, X. et al. (2018) "Destination perceptions, relationship quality, and tourist environmentally responsible behavior", Tourism Management Perspectives, Vol. 28, pp. 93-104, doi: 10.1016/j.tmp.2018.08.001.

Henseler, J., Ringle, C., Sarstendt, M. (2015) "A new criterion for assessing discriminant validity in variance-based structural equation modeling", Journal of the Academy Marketing Science, Vol. 43, pp. 115-135, doi: 10.1007/s11747014-0403-8.

Herington, C., Johnson, L., Scott, D. (2006) "Internal relationships linking practitioner literature and relationship marketing theory", European Business Review, Vol. 18, No. 5, pp. 364-381, doi: 10.1108/09555340610686958.

Hill, S., Tombs, A. (2011) "The effect of accent of service employee on customer service evaluation", Managing Service Quality, Vol. 21, No. 6, pp. 649-666, https://doi.org/10.1108/09604521111185637.

Ho, C., Lee, Y. (2007) "The development of an e-travel service quality scale", Tourism Management, Vol. 28, No. 6, pp. 1434-1449, doi: 10.1016/j. tourman.2006.12.002.

Hua, N. et al. (2019) "What do hotel customers complain about? Text analysis using structural topic model", Tourism Management, Vol. 72, pp. 417-426, doi: 10.1016/j.tourman.2019.01.002.

Huang, H., Chiu, C. (2006) "Exploring customer satisfaction, trust and destination loyalty in tourism", The Journal of American Academy of Business, Cambridge, Vol. 10, No. 1, pp. 156-159, doi: 10.1007/978-3-030-16981-7_5.

Hui, T., Wan, D. (2005) "Factors Affecting Consumers' Choice of a Travel Agency", Journal of Travel \& Tourism Marketing, Vol. 19, No. 4, pp. 1-12, https://doi. org/10.1300/J073v19n04_01.

Hunt, S., Arnett, D., Madhavaram, S. (2006) "The explanatory foundations of relationship marketing theory", Journal of Business \& Industrial Marketing, Vol. 21, No. 2, pp. 72-87, doi: 10.1108/10610420610651296. 
Hunt, S., Morgan, R.M. (1994) "Relationship Marketing in the Era of Network Competition", Marketing Management, Vol. 3, No. 1, pp. 18-28.

Jalilvand, M. et al. (2012) "Examining the structural relationships of electronic word of mouth, destination image, tourist attitude toward destination and travel intention: An integrated approach", Journal of Destination Marketing \& Management, Vol. 1, No. 1/2, pp. 134-143, doi: http://dx.doi.org/10.1016/j. jdmm.2012.10.001.

Jones, T. et al. (2010) "Service customer commitment and responce", Journal of Services Marketing, Vol. 24, No. 1, pp. 16-28, doi: https://doi.org/10.1108/ 08876041011017862.

Jones, T. et al. (2018) "Prototyping analysis of relationship marketing constructs: what constructs to use when", Journal of Marketing Management, Vol. 34, No. 9-10, pp. 865-901, doi: 10.1080/0267257X.2018.1520281.

Kasabov, E., Warlow, A. (2010) "Towards a new model of "customer compliance" service provision", European Journal of Marketing, Vol. 44, No. 6, pp. 700729, doi: 10.1108/03090561011032685.

Kim, A., Brown, G. (2012) "Understanding the relationships between perceived travel experiences, overall satisfaction, and destination loyalty", Anatolia - An International Journal of Tourism and Hospitality Research, Vol. 23, No. 3, pp. 328-347, doi: 10.1080/13032917.2012.696272.

Kim, J., Jin, B., Swinney, J. (2009) "The role of retail quality, e-satisfaction and e-trust in online loyalty development process", Journal of Retailing and Consumer Services, Vol. 16, No. 4, pp. 239-247, doi: 10.1016/j. jretconser.2008.11.019.

Kim, W., Han., J., Lee, E. (2001) "Effects of relationship marketing on repeat purchase and word of mouth", Journal of Hospitality and Tourism Research, Vol. 25, No. 3, pp. 272-288, doi: 10.1177/109634800102500303.

$\mathrm{Ku}$, E., Fan, Y. (2009) "Knowledge sharing and customer relationship management in the travel service alliances", Total Quality Management, Vol. 20, No. 12, pp. 1407-1421, doi: 10.1080/14783360903248880.

Ladhari, R. (2009) "Service quality, emotional satisfaction, and behavioral intentions A study in the hotel industry", Managing Service Quality, Vol. 19, No. 3, pp. 308-331, doi: 10.1108/09604520910955320.

Lenka, U., Suar, D., Mohapatra, P. (2009) "Service quality, customer satisfaction, and customer loyalty in Indian commercial banks", The Journal of Entrepreneurship, Vol. 18, No. 1, pp. 47-64, doi: https://doi.org/10.1177/ 097135570801800103.

Lombard, R., Steyn, T. (2008) "Relationship marketing practices of travel agencies in the Western Cape Province", South African Journal of Business Management, Vol. 39, No. 4, pp. 15-26, https://doi.org/10.4102/sajbm.v39i4.568. 
Medina-Munos, D., Garcia-Falcon, J. (2000) "Successful relationships between hotels and agencies", Annals of Tourism Research, Vol. 27, No. 3, pp. 737-762, doi: 10.1016/S0160-7383(99)00104-8.

Moliner, M. et al. (2007) "Relationship quality with a travel agency: The influence of the postpurchase perceived value of a tourism package", Tourism and Hospitality Research, Vol. 7, No. 3/4, pp. 194-211, doi: 10.1057/palgrave. thr.6050052.

Murphy, L., Mascardo, G. Benckendorff, P. (2007) "Exploring word-of-mouth influences on travel decisions: friends and relatives vs. other travelers", International Journal of Consumer Studies, Vol. 31, No. 5, pp. 517-527, doi: https://doi.org/10.1057/palgrave.thr.6050052.

Namkung Y., Jang S., Choi, S. (2011) "Customer complaints in restaurants: Do they differ by service stages and loyalty levels?", International Journal of Hospitality Management, Vol. 30, No. 3, pp. 495-502, doi: 10.1016/j. ijhm.2010.07.005.

Ndubisi, N. (2007) "Relationship marketing and customer loyalty", Marketing Intelligence and Planning, Vol. 25, No. 1, pp. 98-106, doi: 10.1108/ 02634500710722425.

Ndubisi, N., Chan, W. (2005) "Factorial and discriminant analyses of the underpinnings of relationship marketing and customer satisfaction", International Journal of Bank Marketing, Vol. 23, No. 7, pp. 542-557, doi: 10.1108/02652320510629908.

Ndubisi, N., Nataraajan, R. (2018) "Customer satisfaction, Confucian dynamism, and long-term oriented marketing relationship: A threefold empirical analysis", Psychol Mark, Vol. 35, No. 6, pp. 477-487, doi: https://doi.org/10.1002/ mar.21100.

Negi, R., Ketema, E. (2010) "Relationship marketing and customer loyalty: the Ethiopian mobile communications perspective", International Journal of Mobile Marketing, Vol. 5, No. 1, pp. 113-124.

Nojković, A. (2007) "Modeli diskretne zavisne promenljive: pregled metodologije i primenjenih istraživanja", Ekonomski Anali, Ekonomski fakultet, Beograd, No. 172, pp. 55-92, doi: 10.2298/EKA0772055N.

Nusair, K., Parsa, H., Cobanoglu, C. (2011) "Building a model of commitment for Generation Y: An empirical study on e-travel retailers", Tourism Management, Vol. 32, No. 4, pp. 833-843, doi: 10.1016/j.tourman.2010.07.008.

Oppermann, M. (1999) "Databased Marketing by Travel Agencies", Journal of Travel Research, Vol. 37, pp. 231-237, doi: https://doi.org/10.1177/ 004728759903700303.

Palmatier, R. et al. (2006) "Factors influencing the effectiveness of relationship marketing: a meta-analysis", Journal of Marketing, Vol. 70, pp. 136-153, doi: 10.1509/jmkg.70.4.136. 
Payne, A., Flow, P. (2013) Strategic customer management: integrating relationship marketing and CRM, Cambridge University Press.

Pesonena, J., Komppulaa, R., Murphy, J. (2019) "Plastic loyalty - Investigating loyalty card programs for a Finnish hotel chain", Tourism Management, Vol. 73, pp. 115-122, doi: 10.1016/j.tourman.2019.01.023.

Rajaobelina L. (2018) “The Impact of Customer Experience on Relationship Quality with Travel Agencies in a Multichannel Environment", Journal of Travel Research, Vol. 57, No. 2, pp. 206-217, doi: https://doi.org/10.1177/ 0047287516688565.

Rudež, H. (2010) "Integration of corporate social responsibility into loyalty programs in the tourism industry", Tourism and Hospitality Management, Vol. 16, No. 1, pp. 101-108.

Saha, G., Theingi, C. (2009) "Service quality, satisfaction, and behavioral intentions-a study of low-cost airline carriers in Thailand", Managing Service Quality, Vol. 19, No. 3, pp. 350-372, doi: 10.1108/09604520910955348.

Shammount, A. (2013) Relationship marketing in hospitality, theory and practice, Lambert Academy Publishing, Germany.

Sharma A., Sharma, S., Chaudhary, M. (2020) "Are small travel agencies ready for digital marketing? Views of travel agency managers", Tourism Management, Vol. 79, doi: 10.1016/j.tourman.2020.104078.

Shirazi, F., Som, A. (2013) "Relationship marketing and destination loyalty: evidence from Penang, Malaysia", International Journal of Management and Marketing Research, Vol. 6, No. 1, pp. 95-106.

Siegel, C. (2004) Internet matketing: foundations and applications, Houghton Miffin Company, Boston, USA.

Sin, L., et al. (2002) "The effect of relationship marketing on business performance in a service - oriented economy", Journal of Service Marketing, Vol. 16, No. 7, pp. 656-676, https://doi.org/10.1177/1096348006287863.

Soldić-Aleksić, J., Krasavac, B. (2009) Kvantitativne tehnike u istraživanju tržišta - Primena SPSS računarskog paketa, CID, Beograd.

Song, H., et al. (2011) "Assessing Mainland Chinese tourists satisfaction with Hong Kong using tourist satisfaction indeks", International Journal of Tourism Research, Vol. 13, No.1, pp. 82-96, doi: 10.1002/jtr.801.

Steinhoff, L., et al. (2019) "Online relationship marketing", Journal of the Academy of Marketing Science, Vol. 47, No. 1, pp. 369-393, doi: 10.1007/s11747-0180621-6.

Tortosa-Edo, V., Sanchez-Garc1'a, J., Moliner-Tena, M. (2010) "Internal market orientation and its influence on the satisfaction of contact personnel", The Service Industries Journal, Vol. 30, No. 8, pp. 1279-1297, https://doi. org/10.1080/02642060802348312. 
Tronvoll, B. (2012) "A dynamic model of customer complaining behavior from the perspective of service-dominant logic", European Journal of Marketing, Vol. 46, No. 1/2, pp. 284-305, doi: 10.1108/03090561211189338.

Young, L. (2006) "Trust: looking forward and back", Journal of Business \& Industrial Marketing, Vol. 21, No. 7, pp. 439-445, doi: 10.1108/08858620610708920.

Zhang H. et al. (2014) "Destination image and tourist loyalty: A meta-analysis", Tourism Management, Vol. 40, No. (C), pp. 213-223, doi: 10.1016/j. tourman.2013.06.006.

\title{
Primjena logističkog modela $\mathrm{u}$ analizi marketinških odnosa u turističkim agencijama
}

\author{
Katarina Borisavljevic ${ }^{1}$, Gordana Radosavljević ${ }^{2}$
}

\begin{abstract}
Sažetak
Primjena koncepta relacijskog marketinga u turizmu podrazumijeva izgradnju kvalitetnih odnosa između svih sudionika u turističkom lancu ponude. Osobito je važna analiza pretpostavki za razvoj odnosa i njihov utjecaj na ukupnu uspješnost tvrtki u turizmu. S tim u vezi, predmet rada je istraživanje primjene marketinških odnosa u turističkim agencijama u Srbiji koji posluju na tradicionalan način $i$ putem interneta, te identifikacija ključnih čimbenika lojalnosti korisnika turističkih usluga. Cilj ovog rada je istražiti utjecaj pretpostavki relacijskog marketinga (poput povjerenja, upravljanja pritužbama kupaca, ulaganja u interni marketing, primjene informacijske tehnologije u agencijama, poslovnog imidža i tradicije, kao i socio-demografskih karakteristika klijenata) na izbor putničke agencije preko koje će klijenti putovati. Doprinos rada je u primjeni logističkog modela $u$ istraživanju relacijskog marketinga u agencijama. Važnost rada ogleda se $u$ predlaganju učinkovitog modela primjene koncepta marketinških odnosa u cilju povećanja lojalnosti kupaca u turističkim agencijama.
\end{abstract}

Ključne riječi: relacijski marketing, turističke agencije, logistički model, lojalnost kupaca

JEL klasifikacija: Z33, M31

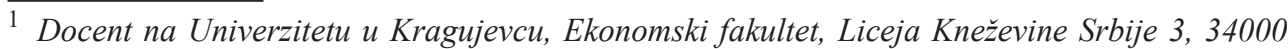
Kragujevac, Srbija. Katedra za Menadžment i poslovnu ekonomiju. Znanstveni interes: marketing i menadžment u turizmu i trgovini. Tel.: +38134303552.E-mail: katarinab@kg.ac. rs. http://www.ekfak.kg.ac.rs/sr/nastavnici/nastavnici-pregled? $i d=156 \& i d d=375$.

2 Redovni profesor na Univerzitetu u Kragujevcu, Ekonomski fakultet, Liceja Kneževine Srbije 3, 34000 Kragujevac, Srbija. Katedra za Menadžment i poslovnu ekonomiju. Znanstveni interes: marketing i menadžment u turizmu i trgovini. Tel.: +38134303568. E-mail: gocar@kg.ac.rs, http://www.ekfak.kg.ac.rs/sr/nastavnici/nastavnici-pregled?id=156\&idd=158. 
Katarina Borisavljević, Gordana Radosavljević • Application of logistics model in analysing...

Zb. rad. Ekon. fak. Rij. • 2021 • vol. 39 • no. 1 • 87-112

\section{Appendices}

Annex 1: Analysis of descriptive statistics

\begin{tabular}{|c|c|c|c|}
\hline & Frequency & Percentages & $\begin{array}{c}\text { Valid } \\
\text { percentages }\end{array}$ \\
\hline \multicolumn{4}{|l|}{ Gender of respondents } \\
\hline men & 159 & 33.9 & 39.9 \\
\hline women & 239 & 51.0 & 60.1 \\
\hline \multicolumn{4}{|l|}{ Education of respondents } \\
\hline high school degree & 175 & 37.3 & 44.9 \\
\hline college (two- year post-secondary educations) degree & 70 & 14.9 & 17.9 \\
\hline university degree & 145 & 30.9 & 37.2 \\
\hline \multicolumn{4}{|l|}{ Travel frequency of respondents } \\
\hline once per year & 207 & 44.1 & 53.1 \\
\hline 2-3 times per year & 160 & 34.1 & 41.0 \\
\hline 4 and more times per year & 23 & 4.9 & 5.9 \\
\hline \multicolumn{4}{|l|}{ Age of respondents } \\
\hline $18-30$ & 137 & 29.2 & 35.1 \\
\hline $31-40$ & 113 & 24.1 & 29.0 \\
\hline $41-50$ & 66 & 14.1 & 16.9 \\
\hline $51-60$ & 63 & 13.4 & 16.2 \\
\hline $61-72$ & 11 & 2.3 & 2.8 \\
\hline \multicolumn{4}{|l|}{ Monthly household income of respondents } \\
\hline $100-500$ euros & 119 & 25.4 & 37.0 \\
\hline $500-1000$ euros & 96 & 20.5 & 29.8 \\
\hline more than 1000 euros & 107 & 22.8 & 33.2 \\
\hline
\end{tabular}

Source: Authors calculation 
Katarina Borisavljević, Gordana Radosavljević • Application of logistics model in analysing... 112 Zb. rad. Ekon. fak. Rij. • $2021 \cdot$ vol. $39 \cdot$ no. $1 \cdot 87-112$

Annex 2: Testing of convergent and discriminant validity

Intercorrelation matrix, average variance extracted (AVE), composite reliabilities (CR) and HTMT results

\begin{tabular}{|c|c|c|c|c|c|c|c|c|}
\hline $\begin{array}{c}\text { Indicator } \\
\text { variables }\end{array}$ & $<---$ & $\begin{array}{c}\text { Latent } \\
\text { variables }\end{array}$ & $\begin{array}{c}\text { Standardised } \\
\text { loadings }\end{array}$ & $\begin{array}{c}\text { Square of } \\
\text { standardised } \\
\text { loadings }\end{array}$ & $\begin{array}{c}\text { Sum of } \\
\text { square of } \\
\text { standardised } \\
\text { loadings }\end{array}$ & $\begin{array}{c}\text { Number of } \\
\text { indicators }\end{array}$ & AVE & $\begin{array}{c}\text { Square } \\
\text { root of } \\
\text { AVE }\end{array}$ \\
\hline CT1 & $<---$ & CT & 0.75 & 0.56 & & & & \\
\hline CT2 & $<---$ & CT & 0.64 & 0.41 & & & & \\
\hline CT3 & $<---$ & CT & 0.74 & 0.54 & & & & \\
\hline CT4 & $<---$ & CT & 0.75 & 0.56 & 2.08 & 4 & 0.52 & 0.83 \\
\hline IM1 & $<---$ & IM & 0.80 & 0.63 & & & & \\
\hline IM2 & $<---$ & IM & 0.65 & 0.42 & & & & \\
\hline IM3 & $<---$ & IM & 0.75 & 0.57 & & & & \\
\hline IM4 & $<---$ & IM & 0.79 & 0.62 & 2.24 & 4 & 0.56 & 0.75 \\
\hline CM1 & $<---$ & CM & 0.61 & 0.38 & & & & \\
\hline CM2 & $<---$ & CM & 0.85 & 0.72 & & & & \\
\hline CM3 & $<---$ & CM & 0.65 & 0.42 & 1.51 & 3 & 0.51 & 0.71 \\
\hline WQ1 & $<---$ & WQ & 0.69 & 0.48 & & & & \\
\hline WQ2 & $<---$ & WQ & 0.74 & 0.56 & 1.03 & 2 & 0.51 & 0.72 \\
\hline
\end{tabular}

Customer trust (CT); internal marketing (IM); compliant management (CM); web quality/web design and content (WQ).

\begin{tabular}{lcccc}
\hline & $\begin{array}{c}\text { Customer } \\
\text { trust }\end{array}$ & $\begin{array}{c}\text { Internal } \\
\text { marketing }\end{array}$ & $\begin{array}{c}\text { Compliant } \\
\text { management }\end{array}$ & $\begin{array}{c}\text { Web design } \\
\text { and content }\end{array}$ \\
\hline Customer trust & 1 & & & \\
Internal marketing & 0.66 & 1 & & \\
Compliant management & 0.63 & 0.59 & 1 & \\
Web design and content & 0.38 & 0.62 & 0.29 & 1 \\
AVE & 0.52 & 0.56 & 0.51 & 0.51 \\
CR & 0.81 & 0.84 & 0.75 & 0.68 \\
\hline
\end{tabular}

\begin{tabular}{|l|l|l|l|l|}
\hline \multicolumn{1}{|c|}{ HTMT } & \multicolumn{1}{|c|}{$\begin{array}{c}\text { Customer } \\
\text { trust }\end{array}$} & $\begin{array}{c}\text { Internal } \\
\text { marketing }\end{array}$ & $\begin{array}{c}\text { Compliant } \\
\text { management }\end{array}$ & $\begin{array}{c}\text { Web design } \\
\text { and content }\end{array}$ \\
\hline Customer trust & & & & \\
\hline Internal marketing & 0.587 & & & \\
\hline Compliant management & 0.638 & 0.580 & & \\
\hline Web design and content & 0.280 & 0.629 & 0.275 & \\
\hline
\end{tabular}

Source: Authors calculation 